\title{
BAIRROS NEGROS DE NATIVIDADE/RJ - MODELO DE EXPANSÃO URBANA DAS POPULAÇÕES NEGRAS NO PÓS- ABOLIÇÃO
}

\author{
Henrique Cunha Júnior ${ }^{1}$ \\ Márcia Aparecida de Souza ${ }^{2}$
}

\begin{abstract}
Resumo: Nos Estados do Rio de Janeiro, Minas Gerais e Espírito Santo as velhas regiões de cafezais dos séculos 19 e início do 20 tiveram grande densidade de populações negras rurais que foram parcialmente substituídas como mão de obra por populações imigrantes europeias. Paralelamente, durante todo século 20 ocorreu o amplo fenômeno de urbanização brasileira. As populações negras da região do norte do estado do Rio de Janeiro, sul do Espírito Santo e de Minas Gerais foram afetadas por um conjunto histórico de fatores que determinou a história dessas populações, como por exemplo os padrões de formação de bairros negros na referida região. São fenômenos de urbanização particulares cujo enfoque ainda é pouco tratado na literatura da urbanização e população negra, como parte da historia urbana do século 20 . O estudo dos bairros negros da Cidade de Natividade é um caso que pode ser generalizado em toda a região. A região tem muitos aspectos em comum tais como, desenvolvimento e crises agrícola, fatores de industrialização, além dos topográficos, como cidades entre rios que resultam em grandes áreas passíveis a inundações e desabamentos.
\end{abstract}

Palavras chaves: Bairros negros; população negra; historia urbana; história do pósabolição.

\section{BLACK NEIGHBORHOODS OF NATIVIDADE / RJ - MODEL OF URBAN EXPANSION OF BLACK POPULATIONN THE POST-ABOLITION PERIOD}

\begin{abstract}
In the states of Rio de Janeiro, Minas Gerais and Espírito Santo, the old coffee plantation regions of the 19th and early 20th centuries had a high density of rural black populations that were partially replaced as labor by European immigrant populations. At the same time, throughout the 20th century, the wide phenomenon of Brazilian urbanization occurred. Black populations in the northern region of the state of

\footnotetext{
${ }^{1}$ Professor Doutor Henrique Cunha Júnior, Grupo de Pesquisa Etnicidade UFBA e UFCE. E-mail: cunhahenrique@yahoo.com ORCID: https://orcid.org/0000-0002-9664-5545 ORCID: https://orcid.org/0000-0003-1430-7233
}

2 Secretaria de Educação, Município de Natividade, RJ. E-mail: profmarciasouza2016@gmail.com ;
\end{abstract}


Rio de Janeiro, southern Espírito Santo and Minas Gerais were affected by a historical set of factors that determined the history of these populations, such as the patterns of formation of black neighborhoods in that region. . These are particular urbanization phenomena whose focus is still little addressed in the literature on urbanization and the black population, as part of the urban history of the 20th century. The study of the black neighborhoods of the City of Natividade is a case that can be generalized throughout the region. The region has many aspects in common such as agricultural development and crises, industrialization factors, in addition to topographical factors, such as cities between rivers that result in large areas susceptible to floods and landslides.

Keywords: Black neighborhoods; black population; urban history; post-abolition history.

\section{BARRIOS NEGROS DE NATIVIDADE / RJ- MODELO DE EXPANSIÓN URBANA DE POBLACIONES NEGRAS EN EL PERÍODO POSTERIOR A LA ABOLICIÓN}

Resumen: En los estados de Río de Janeiro, Minas Gerais y Espírito Santo, las antiguas regiones cafetaleras de los siglos XIX y XX tenían una alta densidad de poblaciones negras rurales que fueron reemplazadas parcialmente como mano de obra por las poblaciones inmigrantes europeas. Al mismo tiempo, a lo largo del siglo XX, se produjo el amplio fenómeno de la urbanización brasileña. Las poblaciones negras en la región norte del estado de Río de Janeiro, el sur de Espírito Santo y Minas Gerais se vieron afectadas por un conjunto histórico de factores que determinaron la historia de estas poblaciones, como los patrones de formación de barrios negros en esa región. . Estos son fenómenos de urbanización particulares cuyo enfoque aún se aborda poco en la literatura sobre urbanización y la población negra, como parte de la historia urbana del siglo 20. El estudio de los barrios negros de la Ciudad de Natividade es un caso que puede generalizarse en toda la región. La región tiene muchos aspectos en común, como el desarrollo agrícola y las crisis, factores de industrialización, además de factores topográficos, como ciudades entre ríos que dan como resultado grandes áreas susceptibles a inundaciones y deslizamientos de tierra.

Palabras clave: Barrios negros; población negra; historia urbana; historia posterior a la abolición.

\section{QUARTIES NOIRS DE NATIVIDADE / RJ - MODÈLE D'EXPANSION URBAINE POUR LES POPULATIONS NOIRES APRÈS L'ABOLITION}

Résumé: Dans les États de Rio de Janeiro, Minas Gerais et Espírito Santo, les anciennes régions de plantations de café du XIXe et du début du XXe siècle avaient une forte densité de populations rurales noires qui ont été partiellement remplacées comme main-d'œuvre par les populations immigrées européennes. Dans le même temps, tout au long du XXe siècle, le vaste phénomène de l'urbanisation brésilienne s'est produit. Les populations noires de la région nord de l'État de Rio de Janeiro, du sud d'Espírito Santo et du Minas Gerais ont été affectées par un ensemble historique de facteurs qui ont déterminé l'histoire de ces populations, tels que les schémas de formation des quartiers 
noirs dans cette région. . Il s'agit de phénomènes particuliers d'urbanisation dont le focus est encore mal traité dans la littérature sur l'urbanisation et la population noire, dans le cadre de l'histoire urbaine du XXe siècle.L'étude des quartiers noirs de la ville de Natividade est un cas qui peut être généralisé à l'ensemble de la région. La région a de nombreux aspects communs tels que le développement agricole et les crises, les facteurs d'industrialisation, en plus des facteurs topographiques, tels que les villes entre les rivières qui se traduisent par de vastes zones sensibles aux inondations et aux glissements de terrain.

Mots clés: quartiers noirs; population noire; histoire urbaine; histoire post-abolition.

\section{1 - INTRODUÇÃO E CONCEITOS}

A história da população negra no Brasil possui um período de fortíssima transição social que compreende o decorrido entre o período do escravismo criminoso e a consolidação do trabalho remunerado e das relações do capitalismo no século XX. A abolição do escravismo criminoso é um longo processo que se inicia muito antes do dia 13 de maio de 1888, data oficial da abolição e que se consolida num tempo histórico bastante posterior, difícil de precisar quando se encerra. Também o pensamento escravista sobre a população negra não se encerra no dia 13 de maio de 1888, pelo contrário, permanece de diversas formas e estabelece um arco de relações que é reproduzida na estrutura do racismo antinegro e das relações sociais do período denominado de pós-abolição. Mesmo a liberdade física do ser negro nas áreas rurais é também difícil de ser determinada, sabemos apenas que uma grande população permaneceu no campo e paulatinamente foi migrando para as cidades. Porém não é possível conhecermos com precisão todas as relações estabelecidas nesses processos, de permanência e de migração entre o campo e as cidades, as próximas e as distantes das áreas rurais. A história da população negra no período do pós-abolição é uma história que está sendo escrita, inclusive através de varias versões, uma dessas é com base na experiência da população negra e na perspectiva dos movimentos sociais da própria população negra. Parte dessa versão é apoiada nos conceitos de africanidade e afrodescendência e é nessa perspectiva que este artigo é escrito. Apoiado em um conjunto de pesquisas ainda em curso nas áreas de urbanismo, geografia e história urbana (SILVA; CUNHA JUNIOR, 2014), (SOUZA; CUNHA JUNIOR, 2011), (SILVA, 2006), (AURELIANO, 2007), (OLIVEIRA; OLIVEIRA, 2015). 
Bairros negros são regiões das cidades que são habitados por maioria da população negra e em parte são localidades que se formaram como resultantado das migrações entre as áreas rurais e as cidades durante o século XX. Esses bairros negros traduzem a experiência das populações negras no período do pós-abolição e constituem uma parte importante da história da população negra na urbanização brasileira. Muito do que tem sido pesquisado e escrito sobre as populações negra urbana é relativo às grandes cidades, sendo diminuta a literatura sobre pequenas cidades como é o caso de Natividade-RJ, localidade tratada nesse artigo.

Os conceitos de africanidade e afrodescendência são decorrentes do Pan Africanismo, corrente de pensamento que entende a condição dos africanos e seus descendentes a partir de uma perspectiva africana, do reconhecimento da existência do racismo antinegro nas relações sociais do sistema capitalista. A africanidade é um conceito proposto por Diop (DIOP, 1963), no qual existe uma unidade africana de conhecimentos e modos de vida, apesar da história de cada localidade produzir diversidade, os fatores unificadores permanecem. A afrodescendência é a atualização da africanidade na diáspora africana realizada nas condições da história brasileira que foram do escravismo criminoso ao capitalismo racista. De acordo com essa concepção, os bairros negros possuem a formação urbana determinada em parte pelos elementos da cultura negra. O bairro negro é uma realidade produzida pelas relações sociais e apresenta um conjunto de fatores materiais e imateriais. Eles constituem a forma urbana das populações negras, são mais que um lugar de moradias, formam um conceito, que implica em tornar específica a história dessa população. Diferenciando de apenas serem consideradas populações pobres ou de classes subalternas, fugindo das generalizações da cultura eurocêntrica (CUNHA JUNIOR, 2019).

As histórias urbanas das cidades brasileiras e principalmente das cidades do interior são pautadas pela invisibilidade ou negação da existência de população negra. Como aponta Maria Nilza da Silva, sobre a cidade de Londrina, na qual a população negra é pioneira no processo de colonização e desaparece na história posterior (SILVA, 2008), da mesma forma ocorre com a população negra de Natividade, no noroeste do Estado do Rio de Janeiro. Daí torna-se fator relevante ao estudarmos os bairros negros a inserção da população negra na história urbana local. Trata-se também de uma contribuição para pensarmos a história da população no período do pós-abolição. 
Neste artigo apresentamos a geografia do território que forma a cidade de Natividade, tratamos do processo de formação dos seis bairros negros e discutimos as condições de inserção das populações negras no processo de urbanização do referido município.

\section{2 - A DINÂMICA HISTÓRICA DA REGIÃO DO RIO CARANGOLA}

A cidade de Natividade se encontra geograficamente entre os estados do Espírito Santo, Minas Gerais e Rio de Janeiro. Para melhor compreensão da história da região é importante evidenciar as bacias dos rios Carangola, Muriaé e Paraíba do Sul, considerando que o povoamento produzido pelos invasores portugueses se deu através da malha fluvial e que os rios faziam parte da forma mais importante de transporte da região até meados do século XIX. A figura 1 apresenta uma panorâmica de um trecho do Rio Carangola. Mesmo o transporte em lombo de animal seguia em parte o leito dos rios. Exemplo típico do desenvolvimento das cidades da região é o município de Muriaé, do lado mineiro, em que a cidade nasce e cresce devido ao rio e o porto da Barra. O povoado cresceu com uma só rua ao longo do rio, dando origem ao "Porto", à "Barra" e à "Armação", em decorrência do rio que margeava e depois disseminando o seu conjunto de casas em todas as direções. A Bacia do Paraíba do Sul é importante para a dinâmica da região devido à navegação de longos trechos e por interligar as economias de São Paulo, Minas Gerais e Rio de Janeiro. A figura 2 apresenta a geografia da bacia do Rio Paraíba do Sul. Trata de bacias hidrográficas confinadas entre as serras da Mantiqueira e a Serra dos Órgãos.

Vários foram os interesses que implicaram na ocupação europeia, seguida de aldeamento dos índios e depois da aplicação de trabalho escravizado de africanos. Os marcos iniciais do denominado desbravamento a região são do século XIX, devido a procura por madeiras de lei, produtos de plantas medicinais, como a raiz da poaia (Ipecacuanha). Depois seguem as plantações de roças de arroz, milho, feijão e a criação de gado. E no século $\mathrm{XX}$, a estrutura econômica da região passa a ser de grandes fazendas de café. 
Figura 1- Panorâmica do rio Carangola, um rio de região montanhosa e de vales profundos

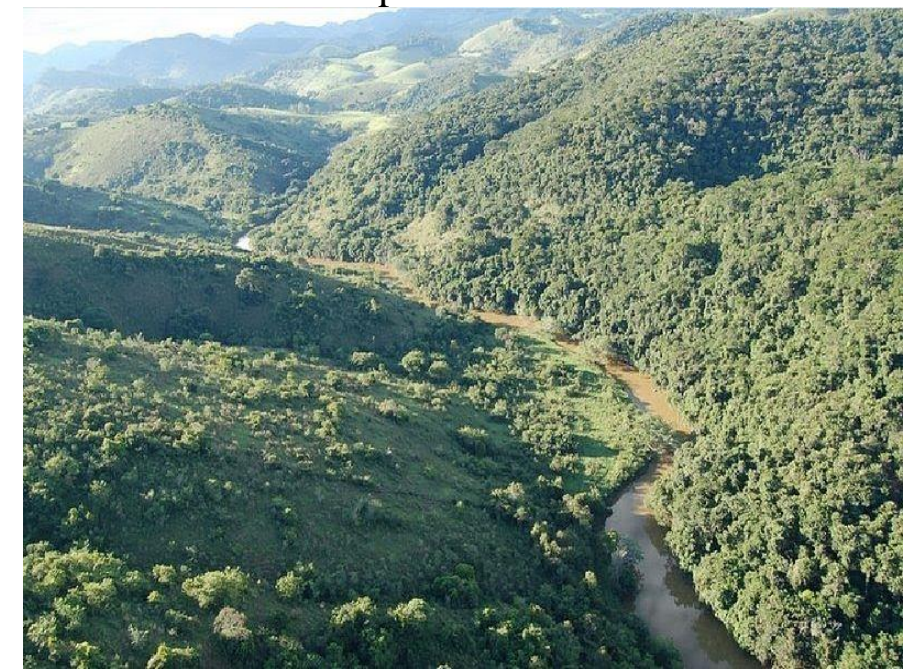

Fonte: https://pt.wikipedia.org/wiki/Rio_Carangola

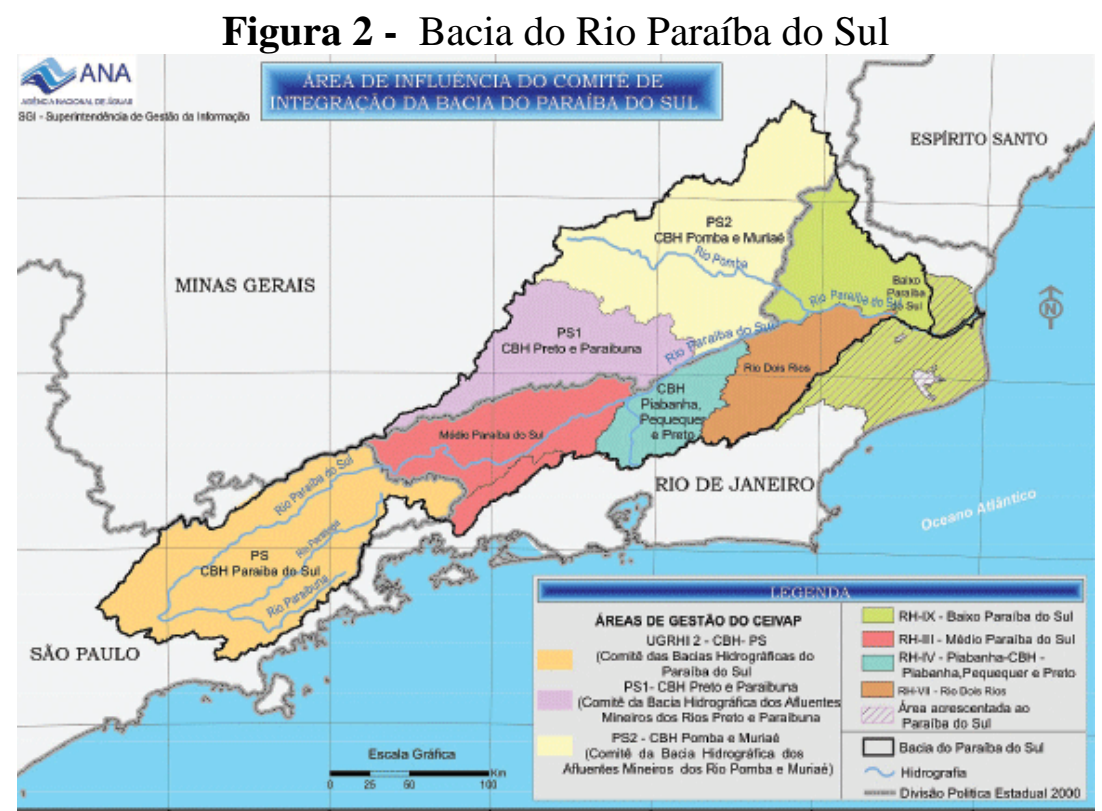

Fonte: Comitês de bacias afluentes do rio Paraíba do Sul - Fonte: INEA(2014)

Entre os séculos XVII e XIX, o ciclo de mineração de ouro e a exploração de diamante em Minas Gerais produziu uma imensa influência sobre a região da bacia do Rio Paraíba do Sul (SILVA, 1995) devido a existência da estrada do ouro ligando as regiões de mineração às portuárias de São Paulo e Rio de Janeiro (SILVA, 1995), (PAIVA, 2002). A estrada do ouro ou estrada real era o caminho onde trafegavam todos os produtos e pessoas entre o Rio de Janeiro e a região de Ouro Preto e Diamantina. Este trajeto exigia pontos de parada, infraestrutura para travessia dos Rios e viveres para 
os animais de carga e seres humanos. A figura 3 apresenta o mapa da estrada real que foi de grande relevância para o desenvolvimento e povoação da região e a formação de territórios de população negra conforme problematiza e demonstra a tese de doutoramento de Renata Aquino da Silva (2018).

Figura 3 - Mapa da estrada real onde o caminho corta a região do Vale do Rio Paraíba do Sul

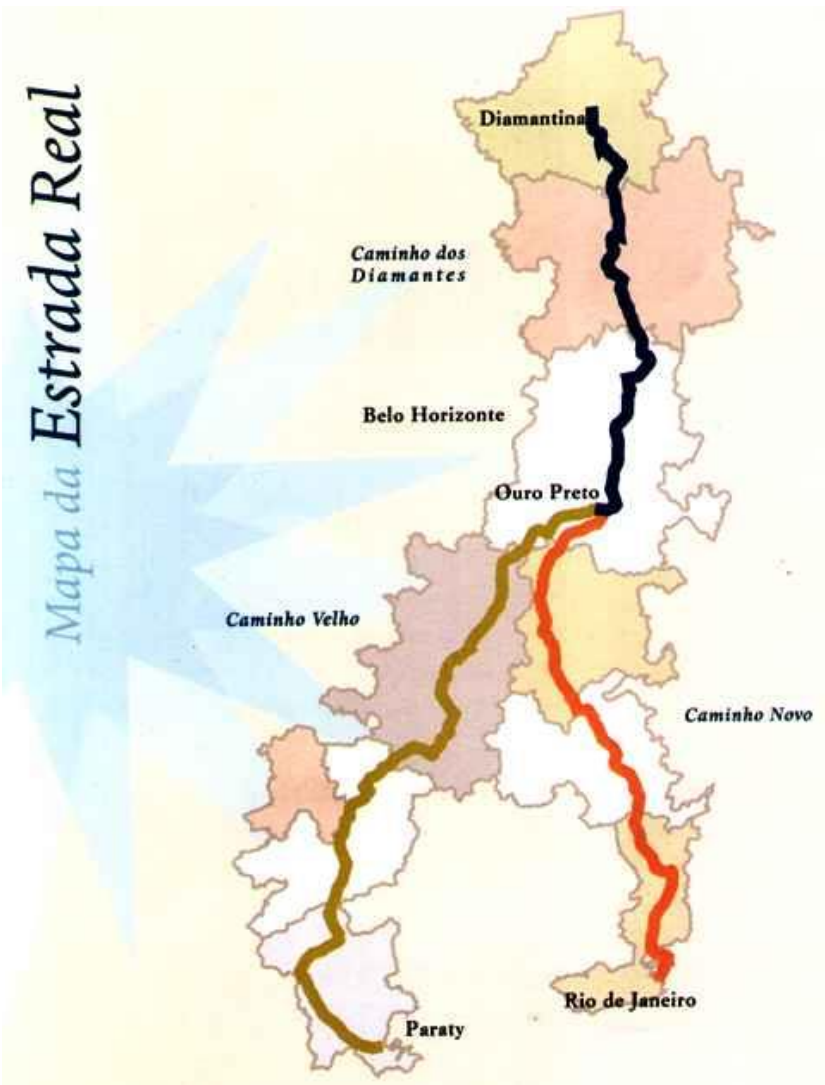

Fonte: http://orebate-cassioribeiro.blogspot.com/2008/06/estrada-real.html

Durante o longo período de ocupação europeia a região dos Rios Carangola e Muriaé foi freada, como parte da região denominada como Sertões da Mantiqueira, devido a uma proibição pela coroa portuguesa de povoamento como forma de reduzir o contrabando de ouro. Apesar de que mesmo existindo tal proibição as populações sempre encontraram formas de burlar a norma e estabelecer exploração da referida região (RODRIGUES, 2003).

\section{3-A GEOGRAFIA E FORMAÇÃO DE NATIVIDADE, AS ÁREAS DE RISCO E AS GRANDES ENCHENTES HISTÓRICAS}


O município de Natividade é considerado urbano, pois atualmente de acordo com do IBGE (2010), a população urbana corresponde a $80 \%$ do total de habitantes. Houve um considerável, contínuo e não planejado crescimento urbano a partir da segunda metade do século XX. Em decorrência desse fator a cidade enfrenta uma série de dificuldades principalmente em épocas chuvosas devido a topografia do município ser morros em torno do Rio Carangola. Em algumas épocas acontecem alagamentos, desmoronamentos, enchentes e falta de água potável, principalmente no verão.

O Rio Carangola, que nasce na serra da Mantiqueira no município de OrizâniaMinas Gerais, a uma altitude de aproximadamente 1500 metros e uma extensão de 295 $\mathrm{km}$ atravessa todo o primeiro distrito, Natividade. Trata-se de um rio de grande vazante e muitas corredeiras. Entre a nascente e a cidade de Natividade existe um desnivel de quase 1200 metros. O Rio Carangola atravessa 6 municípios localizados no estado de Minas Gerais: Orizânia, Divino, Carangola, Faria Lemos, Pedra Dourada e Tombos e 3 municípios localizados no Estado do Rio de Janeiro: Porciúncula, Natividade e Itaperuna, municípios que dependem do Rio Carangola em diversos setores, tais como abastecimento de água de toda a cidade, pesca, matar a sede animais e também para a irrigação das diversas plantações. Em Natividade as águas do rio são captadas pela Companhia Estadual de Água e Esgoto (CEDAE).

Apesar da importância do rio não houve suficiente preocupação em preservá-lo e aconteceu grande desmatamento ao longo de suas margens, bem como seu leito foi afetado por ter sido comprimido pela urbanização, que formou um grande corredor de casas em todo o trecho urbano, transformando-o em fundo de quintais e em depósito de dejetos, o que com o passar do tempo contribuiu para que a população viva o cenário atual, ou seja sinta-se "ameaçada pelas enchentes, que nada mais são do que a retomada do espaço pelas águas do rio outrora invadido”( BEVILÁCQUA,2007).

Enchentes frequentes marcaram a história de Natividade, principalmente da população menos favorecida, os quais construíram suas residências sem planejamento e infraestrutura adequada nas proximidades do rio. E consequentemente são os primeiros e mais prejudicados quando ocorre/ocorreram as cheias históricas do município.

Segundo o Sr. Irandy Alves de Faria, morador de Natividade, pessoas mais antigas relataram a ele que a enchente de 1906, considerado ano do chuveiro, foi uma 
enchente atípica, pois choveu por meses seguidos e as águas subiram a ponto de arrastar a ponte dos velhacos, onde atualmente é a passarela Padre Afonso Alves

Nos anos de 1906, 1979, 1981, 1985,1997, 2003, 2009 e 2020, sucederam grandes enchentes, diversos desabamentos e muitos transtornos.

Inclusive, no ano de 1997 as autoridades municipais do referido ano precisaram decretar Estado de Calamidade Pública. Nesses períodos chuvosos muitas casas desabaram e outras precisaram ser interditadas e inutilizadas devido serem construções muito próximas ao Rio Carangola, em áreas nas quais de forma natural o rio avança em períodos de estiagem ou por serem próximas a barrancos que desabavam sobre casas ou ainda casas que eram soterradas.

\section{4- A EVOLUÇÃo DA POPULAÇÃO E AS SUAS HISTÓRIAS DE FORMAÇÃo}

Natividade-RJ é um dos municípios que compõe a atual região Noroeste Fluminense, antes esse município pertencia a Itaperuna - RJ, que é uma cidade a $30 \mathrm{~km}$ de distância e é considerado o maior e mais importante município da região Noroeste Fluminense.

Natividade também faz divisa com os estados de Minas Gerais e Espírito Santo, figura 4, proximidade que concorre para que se observe semelhanças culturais na culinária, no sotaque e em representação religiosa com os citados Estados. Segundo Pereira Júnior (2015) mesmo a distância física sendo menor entre municípios do Noroeste Fluminense e cidades maiores dentro da hierarquia urbana do Estado do Rio de Janeiro, como Campos dos Goytacazes por exemplo, a população tem preferência por deslocarem-se para cidades mineiras e capixabas como Juiz de Fora e Vitória. 
Figura 4: Mapa do estado do Rio de Janeiro localizando Natividade no retângulo em vermelho

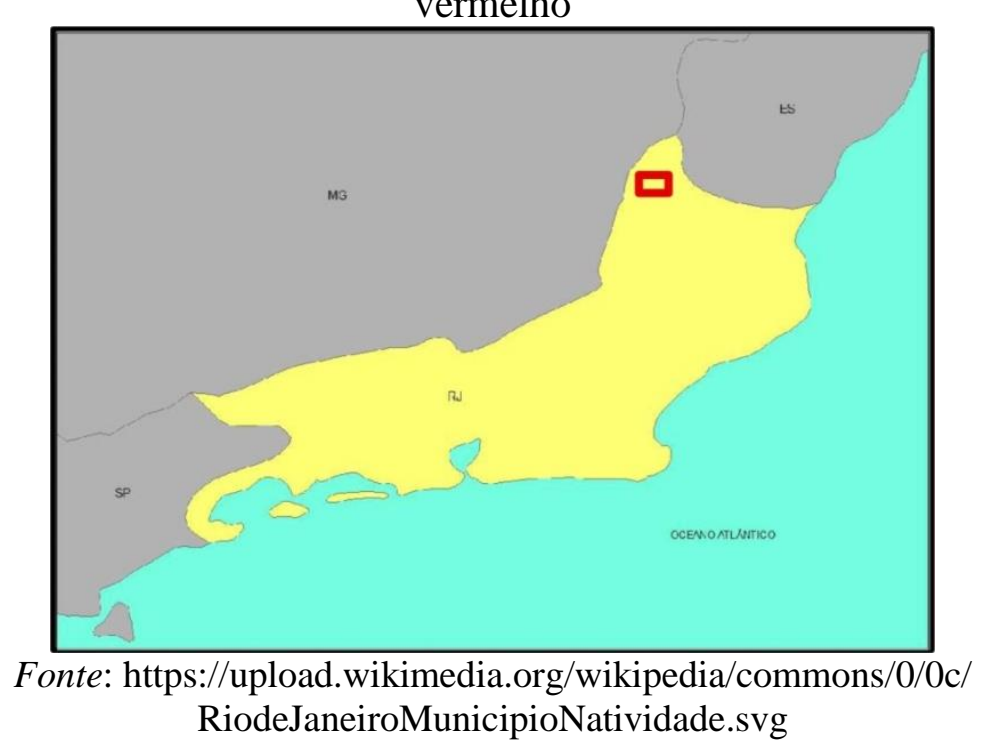

O vale do rio Carangola tornou-se um meio de ligação entre as cidades pois nele transitavam no passado as cargas de mulas para escoar a produção, em suas proximidades foi instalada a estrada de ferro, aproximadamente no ano de 1886 e nele passa a rodovia atual.

Devido maior importância das cidades de Carangola e Itaperuna pelos aspectos econômicos e populacionais, Natividade funciona como satélite dos serviços e comércio dessas cidades. Do ponto de vista histórico a estrada de ferro que funcionou até a década de 1970 por Natividade, a Campos-Carangola, facilitava a ligação entre Natividade e municípios mineiros.

Também a ocupação de Natividade e municípios vizinhos ter contado com a chegada de mineiros que vinham das decadentes Minas de ouro influenciou e aproximou histórica e culturalmente o Noroeste Fluminense e o Estado Minas Gerais.

Ainda segundo Pereira Júnior (2015 p.106) foi constituída uma" rede de trocas que garantiam a subsistência da região toda, assim houve um processo de especialização, como a produção de ervas medicinais em Muriaé, o cultivo de raízes e a produção de cana de açúcar em Itapemirim e o arroz e o milho em Natividade".

A história da colonização das terras que atualmente fazem parte do Município de Natividade teve seu início de ocupação entre os anos de 1821 e 1831; muitas fazendas foram edificadas com a utilização de mão de obra escravizada. A importância 
econômica da região era grande em 1870. Tanto que devido a grande produção de café, viabilizou a implantação da estrade ferro para escoamento da produção em 1880, com inauguração em 1886. Natividade tornou-se municipio independente de Itaperuna em 1947, embora desde 1890 tentava este feito.

Segundo Henriques (1956) de acordo com o entendimento do colonizador a procura pelas terras dessa região aconteceu tardiamente devido à agressividade e rivalidade das tribos indígenas que habitavam essa área. Também dificultava acesso à região os rios serem considerados pouco profundos para navegação e terem leito pedregoso o que contribuía para não atender à demanda de escoamento da produção aurífera da região das Minas Gerais. Principalmente após a decadência da mineração essa região começa a chamar à atenção para a introdução de atividades agrícola que inclusive levou a então região Norte Fluminense, da qual Natividade fazia parte a vivenciarem um produtivo período de riqueza

A ocupação oficial da região se dá a partir de 1831, quando o dito colonizador José de Lannes Dantas Brandão, desertor da polícia de Ponte Nova, Minas Gerais - MG, chega a essa região e ocupa o espaço por ele denominado Conceição e constrói uma grande fazenda. Um pouco mais tarde com a lei de incentivo ao estabelecimento de colônias agrícolas em áreas ainda não desenvolvidas outros parentes do branco colonizador recebem terras à margem esquerda do rio Carangola onde foram construídas outras fazendas. São patrimônios do período escravista as grandes casas de fazenda preservadas na região como a apresentada na figura 5.

Figura 5 - Fazenda São José (1834)

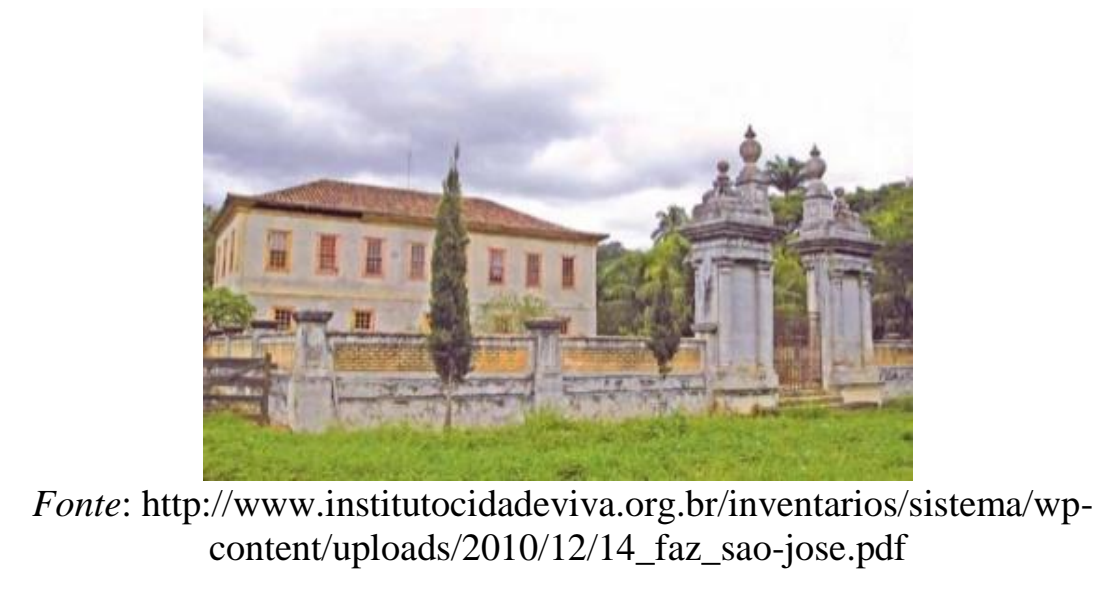


Sobre a população negra que habitava a região e certamente serviram de mão de obra na construção das muitas fazendas da localidade poucos relatos são encontrados. Porém o censo de 1872 contabilizou que em Itaperuna (município do qual Natividade foi distrito) havia uma população livre de 3.803 entre mulheres e homens para uma população escravizada que somava 1.832 negros e negras. Essa população livre também incluía a população negra livre. Cabe destacar que quase a metade da população era escravizada.

Nessas fazendas havia grandes plantações de diversos produtos tais como milho, arroz, algodão cana de açúcar, entre outros. Mas o café foi o principal produto cultivado durante anos, foi o motor que impulsionou a economia da região e tornou-se tradição em Natividade, principalmente nas terras que hoje formam o município de Varre-Sai. Inclusive a região chegou a ser considerada uma das maiores produtoras do Brasil.

Dados visíveis como, por exemplo, o perfil étnico atual da população de Natividade nos leva a entender que havia nesse período forte presença de população negra na localidade. Também evidenciam essa ideia a existência de velhos casarões na parte central da cidade, marcas de um fausto econômico, dinamismo e desenvolvimento de uma região. Indícios da ancienidade dos efeitos de povoamento por populações de africanas e descendentes, por população negra e períodos do trabalho escravista. De forma que a não existência de dados estatísticos sobre a mão de obra escravizada que atuou na agricultura, nas construções e nas manobras dos engenhos, não implicam em ausência do trabalho escravizado (CUNHA JUNIOR, 2011).

Também, Carvalho (2001) relata que houve uma grande colheita de café na Fazenda Bela Vista em abril de 1898 época que já havia chegado naquela fazenda imigrantes italianos para atuarem na produção. Porém, como para uma colheita é necessário a partir do plantio das mudas aguardar um espaço de tempo de 3 a 4 anos, depreende-se que foi utilizada mão de obra de negros escravizados ou livres, para o plantio e cuidados com as lavouras de café; pois os imigrantes italianos que foram para a referida fazenda chegaram em Natividade a partir de 1896.

A região central do município de Natividade começou a se desenvolver às margens do rio Carangola em um período que a população pobre, entre eles escravos/ livres e camponeses, ainda trabalhavam nas roças nas diversas plantações que havia. 
Após a dita abolição e o declínio do café essa população negra e pobre começou a migrar para área urbana de Natividade à procura de trabalho pois houve por parte do Estado brasileiro um processo de desqualificação social da população negra, que perdeu seus postos de trabalho para outras populações (CUNHA JUNIOR, 2010). Ao chegarem à área urbana começaram eles mesmos a construírem suas casas em morros e também às margens do rio, mas não na região Central, pois essa já havia sido ocupada pela elite Natividadense.

\section{1-O CENTRO DE NATIVIDADE}

A área central é o lugar em que se concentra as atividades comerciais mais relevantes além de bancos, correios e farmácias. Ao longo dos anos o município passou por transformações na paisagem urbana e por pequena verticalização. Umas das maiores alterações que aconteceu no traçado urbano central foi a retirada das árvores, que foram plantadas no meio da avenida principal (Figura 6), em toda a extensão do centro da cidade, e que dividia a avenida principal e demarcava a segregação racial e social que havia na área central. Segundo relatos dos antigos moradores à direita transitava a comunidade negra e à esquerda transitava a comunidade branca e de boa situação econômica. Também na região central, no Clube Lítero Esportivo de Natividade (CLEN), sede social, os negros eram barrados, conforme relatos de natividadenses que preferiram não se identificar.

O centro de Natividade que era calçado com paralelepípedos foi asfaltado modificando a infraestrutura das ruas (Figura 7). O asfaltamento faz parte da ideologia do progresso, pois imita as grandes cidades e torna a circulação de automóveis mais suave, no entanto produz custos para o município, pois as pedras é de produção local e o asfalto vem de fora. Nas últimas décadas foram inaugurados 04 prédios que além de apartamentos residenciais também possuem consultórios médicos, odontológicos e psicológico, escritórios de advocacia e rádios. Trata-se do início da verticalização das edificações no centro da cidade. 


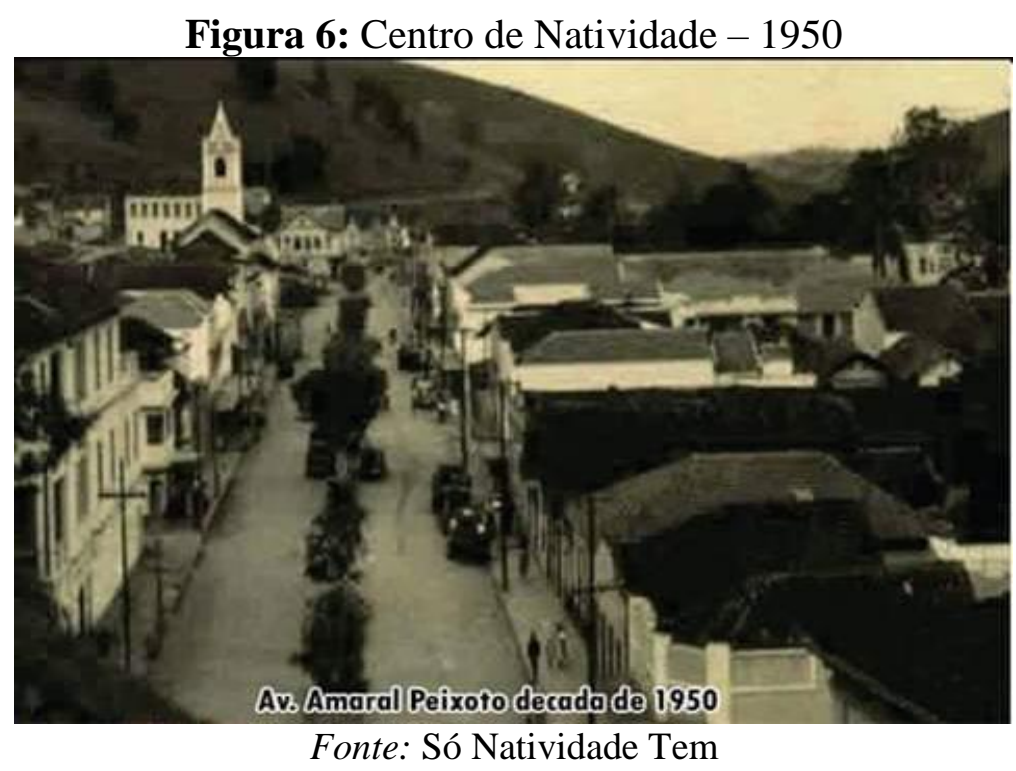

Figura 7: Centro de Natividade- 2019

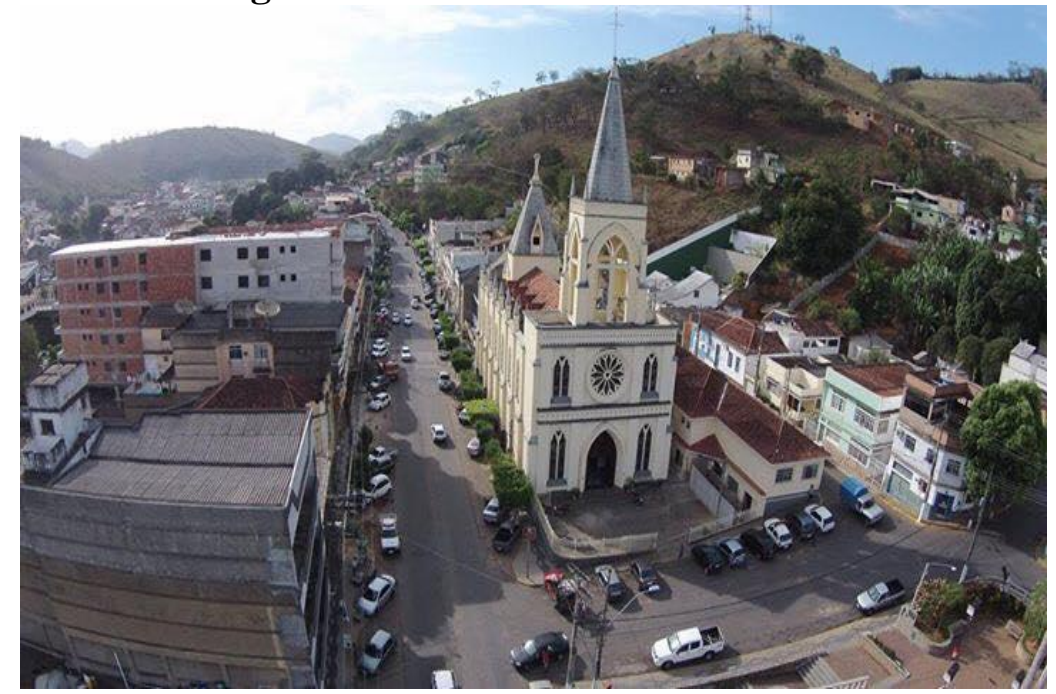

Fonte: https://www.ativanatividade.com.br/galeria_de_fotos/natividade-rj/

Ainda na área central, porém na parte mais alta desta localidade, encontra-se o Morro do Castelo, Castelândia, Morro do Areião e Encosta do Sol. Todos, bairros predominantemente residências e que abrigam uma população também considerada elitizada e em grande maioria de população branca.

\section{5- BAIRROS NEGROS DE NATIVIDADE.}


Na formação da cidade observamos períodos distintos, o dos bairros mais antigos e de marcadores de população negra mais persistentes, reconhecidos pela população da cidade e os novos bairros, nesses existem as formações mais atuais nas quais aparecem visíveis marcas do estado na constituição dos referidos bairros.

\section{1- FORMAÇÃO DOS BAIRROS ANTIGOS.}

Os bairros apresentados a seguir são espaços de maioria negra, locais marcados por especificidades tanto materiais quanto imateriais dessa camada da população; espaços de enfrentamento e superação de problemas. Portanto, torna-se necessário um olhar diferenciado e específico para esses espaços, designados "bairros negros" locais que evidenciam formas de inclusão social e superação de racismo (CUNHA JUNIOR 2005). Os primeiros bairros negros são denominados como: Bairro do Pito, Morro dos Cabritos e Cantinho do Fiorello. O mapa da figura 8 assinala a distribuição dos bairros negros no município de Natividade.

Figura 8: Bairros de Natividade-RJ

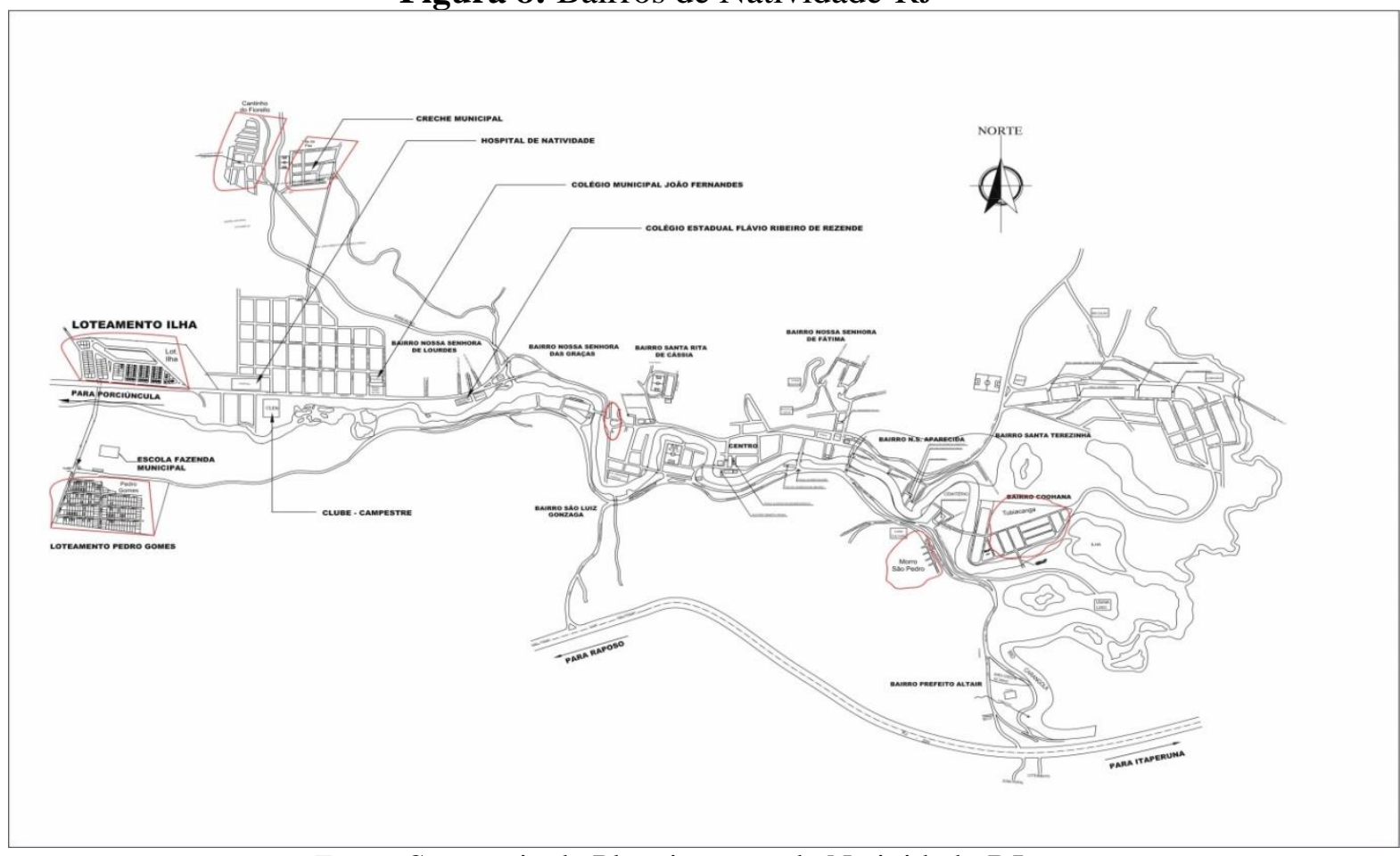

Fonte: Secretaria de Planejamento de Natividade-RJ 


\section{O BAIRRO PITO}

A intensificação da população urbana negra data de 1940 em diante. Devido a crise no campo e a desvalorização da mão de obra negra houve um deslocamento populacional das roças para as cidades, que fez com que a população negra sem recursos se espalhasseam pelo núcleo populacional denominado Pito, bairro formado por uma parte alta, Ladeira São Cristóvão e uma parte baixa às margens do Rio Carangola. Segundo Relatos orais o Bairro era formado por vários ranchinhos de sapé, às margens do rio Carangola. Local em que moravam pessoas pobres, que trabalhavam muito, principalmente, mulheres que passavam o dia a lavar roupas na beira do rio. Entre os Moradores havia uma senhora, chamada Dona Maria, que ao anoitecer, após concluir o trabalho do dia, sentava-se num banquinho de madeira, na porta de sua casa para descansar e acendia um velho cachimbo de bambu, conhecido como pito. Como não havia eletricidade, a luz do cachimbo era vista pelas pessoas que passavam, que a cumprimentavam e perguntavam se ela estava bem. Ao que ela respondia: "Tô bem, aqui com meu pito aceso". Segundo relatos orais foi em decorrência dessa história que esse bairro recebeu o nome de Pito, como ainda é conhecido.

A maioria das casas eram simples, construídas de pau a pique e cobertas com sapé. Os moradores, alguns trabalhavam em fazendas vizinhas, na agricultura e na pecuária. Outros, tanto homens quanto mulheres enquanto havia armazéns de café e arroz exerciam suas atividades laborais, nesses. Os homens realizavam trabalho braçal duro, mas era o único que lhes era oferecido na zona urbana e que permitia a subsistência de suas famílias, carregavam e descarregavam sacas de café, arroz entre outros produtos. As mulheres por sua vez trabalhavam por exemplo, na 'cata' de café nos armazéns, separavam os grãos e os ensacava para os homens carregá-los. E quando os armazéns fecharam as mulheres passaram a trabalhar em casas de família; os homens faziam "bicos"e trabalhavam na agricultura e pecuária nas roças próximas. Alguns conseguiram trabalho como braçal da Prefeitura da cidade. Naquela ocasião, ainda não era obrigatório concurso público.

Com o passar do tempo essa população cresceu, o número de casas aumentou e enfrentou muitos problemas em épocas de chuva tanto em relação a desmoronamentos 
quanto às enchentes pois essa comunidade divide-se em uma parte alta, Ladeira São Cristóvão e uma parte baixa, na qual o correr de casas fica estre o Rio Carangola, nos fundos e a estrada que dá acesso ao município vizinho, Porciúncula e aos municípios mineiros.

Segundo relatos de antigos moradores a referida ladeira São Cristóvão, que possuía dois correres de casa, na década de 70 perdeu o correr de baixo, que dá para a estrada. As casas, de maioria de moradores negros, ruíram em um período de chuvas prolongado. Porém, como as casas foram dando sinais (rachaduras) que iriam desabar, apesar das pessoas perderam tudo, não houve vítimas. Moradores ficaram desabrigados e alguns passam a residir no Morro São Pedro (Popular Morro dos Cabritos), que será abordado a seguir.

Nessa mesma comunidade em 2009 aconteceu outra tragédia envolvendo casas; dessa vez moradias da rua de baixo, as quais dão fundos para o rio, deslizaram para dentro do Rio Carangola. (SOUZA; CUNHA JÚNIOR, 2019)

\section{MORRO DOS CABRITOS OU MORRO SÃO PEDRO}

Localizado próximo à área central, acima do Bairro Liberdade em uma área bastante íngreme que era utilizada para criação de cabritos. Foi loteado por volta de 1963, as posses foram cortadas e doadas pelo prefeito da época, conforme prometera. Composto por um público predominantemente negro, recém-chegados da zona rural, por pessoas que ficaram desabrigadas devido residirem em área afetadas por enchente e desmoronamentos, como o que ocorrera no bairro Pito, por exemplo, e outros que pagavam aluguel; enfim foram doadas para um público de baixa renda. Houve o desenvolvimento de uma área periférica, caracterizada dessa forma por abrigar uma população carente de recursos econômicos e que consequentemente construíram suas residências de acordo com os recursos mínimos que conseguiam obter. A princípio foram construídas muitas habitações de pau a pique sem infraestrutura e sem supervisão da aplicação das normas urbanas. Outro agravante para as construções era o morro ser alto e sem calçamento, o que dificultava a subida de caminhões por exemplo. Surgiu então uma área segregada, pobre e carente, inclusive de saneamento básico. No decorrer dos anos, as famílias foram aumentando e muitas novas construções surgiram, essas 
também feitas sem planejamento prévio, o que culminou em constantes desabamentos em épocas chuvosas. Tanto que na década de 1980 em decorrência de chuvas, grande número de residências do referido bairro ruíram e a população desabrigada precisou ser alocada em barracas de lona no Bairro Balneário até que novas residências foram providenciadas. Surgiu assim um novo bairro em Natividade denominado Vila da paz, que abrigou a população que aguardava entre outros.

Ainda sobre o popular Morro dos Cabritos, que posteriormente passou a ser denominado Morro São Pedro, com o tempo houve diversas melhorias e a população passou a contar com água potável, energia elétrica, coleta de lixo e asfaltamento, enfim recursos básicos para sobrevivência.

\section{CANTINHO DO FIORELLO}

Segundo relatos de moradores a comunidade do Cantinho do Fiorello recebeu essa denominação devido a primeira casa construída naquela localidade pertencer ao Sr. Fiorello Zambrotti, que possuía uma pequena propriedade no local. Moradores antigos afirmam que na década de 70, havia apenas 2 ou 3 casas e os moradores dessas dividiam cercas com pastos de criação bovina. Os terrenos da parte baixa do Cantinho foram vendidos pela família Baião a pessoas que estavam saindo da zona Rural para tentar morar mais próximo à cidade com intenção de conseguir trabalho que estava escasseando na zona rural. Quanto à parte alta muitas posses foram doadas e casas improvisadas e sem infraestrutura básica foram construídas em encostas que ofereciam risco em períodos chuvosos. As casas da parte mais baixa também apresentavam precária infraestrutura. Na referida localidade não havia saneamento básico, os moradores utilizavam água de uma nascente para todas as necessidades, usavam lamparinas ou velas, não havia calçamento, nem redes e esgoto, resolviam essa situação através da utilização de fossas.

Os homens trabalhavam na colheita de café em Varre- Sai, que na época era distrito de Natividade, ou em fazendas nas proximidades. As mulheres levantavam-se de madrugada para organizar marmita para o marido levar para o trabalho. Havia um caminhão que apanhava os homens nas primeiras horas da manhã e retornava com eles 
por volta das 18 horas; também, as mulheres trabalhavam como lavadeiras, o que não era fácil devido haver apenas água do poço, na época.

Os proprietários das terras (pasto) do Cantinho do Fiorello após alguns anos providenciaram uma bomba manual que "puxava" a água e essa "corria"por um cano. As pessoas faziam fila para bombear água, encher as latas ou baldes para levarem para suas casas.

Como não havia escola por perto, mesmo esse bairro sendo considerado urbano, fica a aproximadamente $06 \mathrm{~km}$ do centro da cidade, o prefeito da época alugou uma casa recém construída, para ser utilizada como escola. E nessa casa a escola funcionou por muitos anos. Durante décadas a população local conviveu com sérios problemas devido a falta de saneamento básico, mas atualmente essas questões já foram solucionadas e a população que reside no Cantinho do Fiorello conta com saneamento.

Nessa localidade residem muitas famílias menos favorecidas e grande parte das casas foram construídas através de processo de autoconstrução e sem os necessários serviços de infraestrutura urbana.

A localidade apresenta um relevo acidentado com áreas de risco nas partes mais alta do morro inclusive, a situação parece agravar-se devido a novas ocupações que são construídas também de forma bastante precária. Nas partes mais íngremes o acesso às moradias se dá através de escadões.

\section{VILA DA PAZ}

Na década de 80, quando as casas da Vila da Paz foram entregues aos moradores faltava água tratada, pavimentação, energia elétrica, tratamento de esgoto e transporte público. Já de início os moradores também sofriam com a exclusão e segregação, chegavam inclusive a serem chamados de moradores da "Vila Miséria". Após alguns anos houve diversos melhoramentos e a população pode contar com saneamento básico, uma escola, uma creche, um Posto de Saúde Familiar, igrejas, pequenos mercados e com um Centro de Referência da Assistência Social. Quanto ao lazer a situação ainda é delicada, a população conta apenas com uma quadra coberta em precárias condições de uso e que serve tanto à Vila da Paz quanto ao Cantinho do Fiorello. Essa comunidade surgiu devido a um grande número de Natividadenses ficarem desabrigados. Perderam 
suas casas em decorrência de enchente e deslizamentos de terra naquele período, muitos dos desabrigados eram do Morro São Pedro e Pito (SOUZA e CUNHA JÚNIOR, 2019).

A área ocupada pela Vila da Paz é um exemplo de população localizada em local periférico, ou seja, que cresce para espaços mais afastadas e sem estrutura e de que a periferização não é mais um fenômeno único das grandes cidades, visto que Natividade é uma cidade pequena. Também após aproximadamente três décadas, aquela comunidade cresceu bastante, muitos outros moradores chegaram, principalmente pessoas com baixo nível de renda, passaram a migrar para a referida comunidade; outros por preferirem moradias mais afastadas. E com isso a população passa também a enfrentar sérios problemas como expansão irregular e construções sem infraestrutura ocasionando possíveis riscos. Além disso já inicia situações de violência e outras situações causadas principalmente pela falta de políticas públicas que favoreçam a mulheres, crianças e adolescentes.

Vale a pena observar que violência está presente em muitos lugares, independente de ser o bairro periférico ou não. "Mas isso ainda está relacionada às questões de pobreza e miserabilidade da periferia. É preciso uma coerência política nos espaços locais que adotem ações para reduzir os riscos sociais, devido à evolução da pobreza"(PAULA, 2018 p.80).

A vulnerabilidade e por vezes invisibilidade que há em certas áreas, acaba gerando situações de violência e marginalização. E como é frequente em locais suburbanos a falta ou escassez de recursos financeiros, bem como há mínimas perspectivas de futuro, depreende-se que vulnerabilidade é consequência da segregação.

\section{PEDRO GOMES}

Com o crescimento do déficit habitacional no final da década de 1990, o então prefeito de Natividade desapropriou uma área de propriedade do Sr. Pedro Gomes e passou para pessoas que moravam em áreas de risco, outros que eram beneficiados com aluguel social entre outras necessidades. Devido o espaço físico ter pertencido ao Sr. Pedro Gomes a localidade ficou conhecida por essa denominação.

As casas foram construídas com recursos próprios dos proprietários dos lotes. Algumas sem infraestrutura, outras com algumas deficiências e outras melhor 
estruturadas. O saneamento ainda é precário principalmente quanto a pavimentação das ruas.

Esse bairro é bastante distante do centro da cidade e não há transporte público para facilitar o acesso dos moradores à área central para suprir suas necessidades básicas para sobrevivência, tais como ir a mercados, escola, comércio, bancos, lojas ou a seus locais de trabalho. Além da distância para terem acesso à área central da cidade, outro complicador à utilização de veículos automotores é que a estrada ainda não é pavimentada nem possui iluminação pública; Após alguns foi construída uma passarela, para pedestres e ciclistas, esses com alguma dificuldade, através da qual a população local tem o acesso facilitado à área pavimentada de outro bairro.

Esse distanciamento além de gerar uma segregação sócio espacial, requer grandes gastos futuros pois entende-se que há necessidade de que a infraestrutura urbana cresça para essa área.

\section{2 - NOVOS BAIRROS NEGROS}

\section{TUBIACANGA}

Esse bairro também foi criado no final da década de 1990, com o objetivo de abrigar famílias que estavam com problemas de moradia devido a dificuldades de pagar aluguel, desemprego, chuvas em anos anteriores e famílias recém-formadas.

Quando as unidades habitacionais foram entregues na localidade não havia nenhum comércio, serviço de saúde ou escola (Figura 9). Os moradores precisavam locomoverem-se por mais de $5 \mathrm{~km}$ para terem acesso a esses serviços. Apesar de localizar-se relativamente perto da área central não há como ter acesso a essa devido o Rio que circula a parte que seria de acesso ao Bairro Liberdade, próximo ao centro da cidade.

Mesmo havendo famílias com diferentes números de filhos, as casas seguiam uma única tipologia, com um pequeno quintal passível à reforma e ampliação. A construção de novas moradias é produção de "cidades, porém estas que atualmente são produzidas são marcadas por profundas expressões de desigualdades e exclusões sócio territoriais", sendo que deveria haver preocupação em realizar construções que 
privilegiassem o bem-estar dos moradores para um agradável desenvolvimento das pessoas (ROLNICK, 2009, p.2).

Figura 9: Bairro Tubiacanga

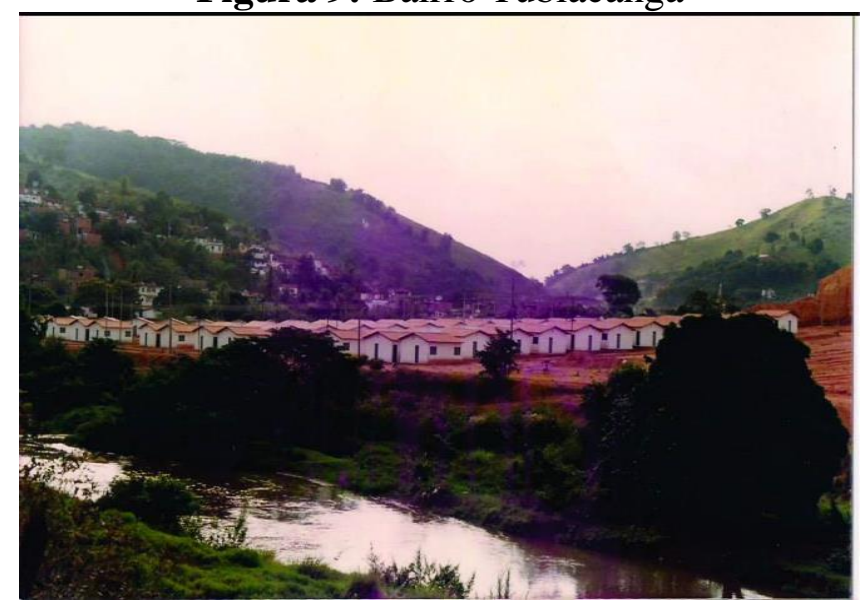

Fonte: https://www.facebook.com/sonatividadetem

Figura 10: Loteamento Ilha

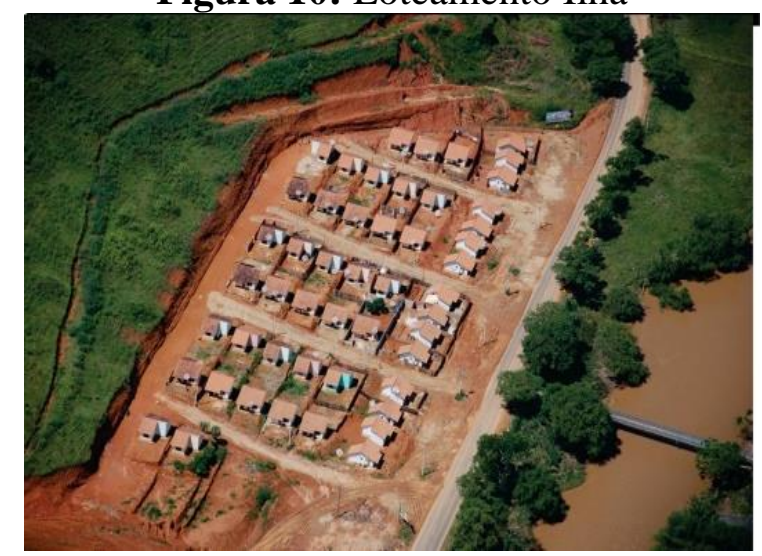

Fonte: https://www.facebook.com/sonatividadetem

\section{LOTEAMENTO ILHA}

Situado em área periférica da cidade de Natividade, à beira da estrada RJ 220 e próximo ao Rio Carangola. Inicialmente o loteamento possuía 50 casas (Figura 10) divididas em blocos, localizados em ruas transversais. Quando as casas foram 
entregues, prioritariamente às mulheres, no ano de 2008, havia pouca iluminação e precária pavimentação. Após algum tempo mais casas foram construídas e entregues a outras pessoas que apresentavam problemas de moradis. Após a entrega aos moradores já se pode observar algumas benfeitorias tais como, pavimentação e um calçamento com alguns postes de iluminação nas proximidades da estrada RJ 220.

O loteamento, que possui maioria de moradores negros e pobres, já está estigmatizado como violento e perigoso e apelidado por "Espanha" (Eles panham).

Observa-se que grande parte dos moradores ainda são jovens, também há muitas mulheres chefes de família que trabalham com faxinas ou são empregadas doméstica. É grande o número de jovens e crianças no loteamento, grupo etário ingressos ou que estão ingressando-se nas escolas, o que causa bastante preocupação devido a localização e proximidade da comunidade com a estrada, pois muitos jovens utilizam-se de bicicletas para o translado à escola e para tanto precisam atravessar a estrada que é bastante movimentada. Situação que se torna cada dia mais preocupante devido a acidentes fatais que vem ocorrendo no local, em outubro de 2018 uma criança de 5 anos veio a óbito atropelada por um veículo automotor e em fevereiro de 2020 um jovem de 20 anos foi vítima fatal de um acidente envolvendo moto e caminhão, quando a vítima precisou desviar-se de um cachorro.

\section{6- ÁREAS DE RISCO- NATIVIDADE-RJ}

\section{Figura 11: Tabela com respectivos bairros das áreas de risco de Natividade-RJ}




\begin{tabular}{|c|c|c|c|c|}
\hline HIERARQUIA & BAIRRO & LOCALIZAÇĀO DE PONTO & $\begin{array}{l}\text { MORADIAS SOB } \\
\text { RISCO }\end{array}$ & $\begin{array}{l}\text { PESSOAS } \\
\text { SOB RISCO }\end{array}$ \\
\hline 1 & Morro da Formiga & ND-LM-14 - Rua Imaculado Sagrado Coração de Jesus 39,41 e s/n & 19 & 76 \\
\hline 2 & Popular Velha & ND-PR-24 - Rua Acadêmico Ézio Freitas N ${ }^{*} 13,17,19,21$ e 3 casas S/N & 6 & 24 \\
\hline 3 & Morro Säo Pedro & ND-PR-02 - Rua Antônio da Costa Saraiva $303,333,3$ casas SIN & 5 & 20 \\
\hline 4 & Sindicato & ND-LM-11 - Ladeira São Cristơvão 28 e casas SIN & 4 & 16 \\
\hline 5 & Morro Săo Pedro & ND-PR-01 - Rua Antônio da Costa Saraiva & 4 & 16 \\
\hline 6 & Morro São Pedro & ND-PR-07 - Rua Antônio de Castro Maia, casa s/n & 4 & 16 \\
\hline 7 & Morro Säo Pedro & ND-PR-05 - Rua Antônio da Costa Saraiva 173,179,5/n & 3 & 16 \\
\hline 8 & Cantinho do Fiorelo & ND-LM-01 - Rua Projelada casas s/n & 3 & 13 \\
\hline 9 & Cantinho do Fiorelo & ND-LM-06 - Rua Projetada, casas s/n & 3 & 12 \\
\hline 10 & Morro do Areião & ND-LM-21 - Rua Nossa Senhora de Fátima 167,170 e s/n & 3 & 12 \\
\hline 11 & Morro Săo Pedro & ND-PR-03 - Rua Antônio da Costa Saraiva em frenta a casa 299 & 3 & 12 \\
\hline 12 & Cantinho do Fiorelo & ND-LM-05-Rua Projetada, casas s/n & 2 & 8 \\
\hline 13 & Cantinho do Fiorelo & ND-LM-09 - Rua Doutor Carlos Cavalcante, casas sin & 2 & 8 \\
\hline 14 & Morro do Areiăo & ND-LM-25 - Rua Giorgino Dutra Werneck, casas sin & 2 & 8 \\
\hline 15 & Centro & ND-PR-11 - Rua Governador Portela 38 & 1 & 6 \\
\hline 16 & Balneário & ND-LM-12 - Rua José Batista Ramos & 1 lgreja e 1 casa & 4 \\
\hline 17 & Cantinho do Fiorelo & ND-LM-08 - Rua Doutor Carlos Cavalcante 513 & 1 & 4 \\
\hline 18 & Centro & ND-PR-13 - Rua Antônio Ferreira Rabelo 231 & 1 & 4 \\
\hline 19 & Vila da Cunha & ND-PR-17 - Rua José Delanis 238 & 1 & 4 \\
\hline 20 & Popular Velha & ND-PR-25 - Rua Académico Ézio de Freitas,fundos da casa sin & 1 & 4 \\
\hline 21 & Morada do Engenho & ND-PR-21 - Rua Antônio da Silva Campos,casa sinn & 1 & 4 \\
\hline 22 & Cantinho do Fiorelo & ND-LM-03 - Rua Projetada casa sin & 1 & 4 \\
\hline 23 & Pito & ND-LM-13-Rua José Batista sinn & 1 & 1 \\
\hline \multirow[t]{2}{*}{24} & Vila da Cunha & ND-PR-18 - Rua Vereador Aceu Lannes Tinoco,lgreja Padre Moacir & 1 Igreja & 0 \\
\hline & & TOTAL & 74 & 292 \\
\hline
\end{tabular}

Fonte: file:///C:/Users/marci/Downloads/natividade\%20(4).pdf 


\section{Q

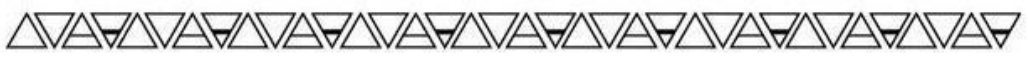

Figura 12: Mapa de áreas de risco em Natividade-RJ

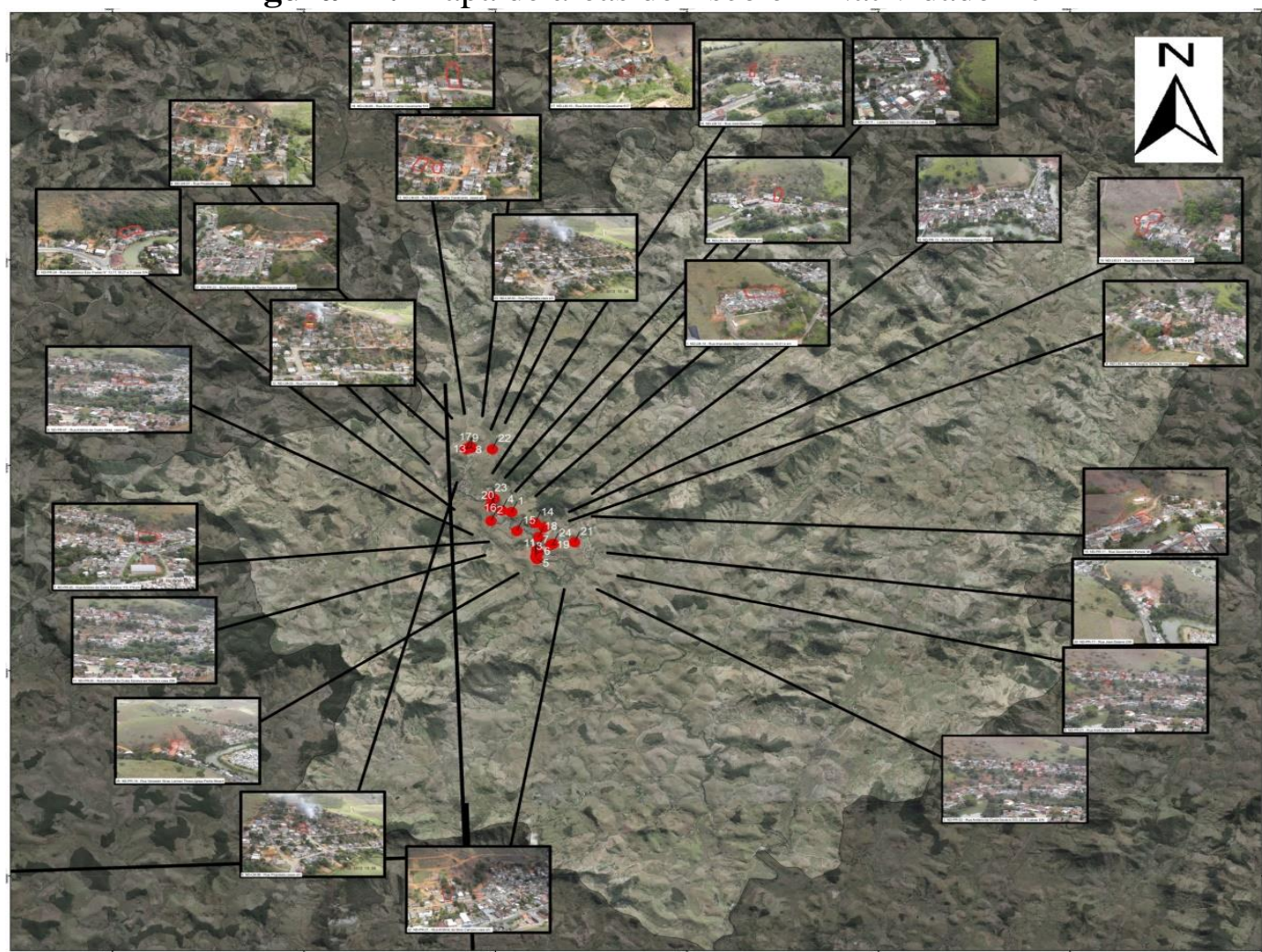

Fonte: file:///C:/Users/marci/Downloads/natividade\%20(4).pdf

Os espaços urbanos estão se tornando cada vez menores, visto que o quantitativo de moradias cresceu desordenadamente, o que culmina em construções em terrenos impróprios e não recomendáveis principalmente nos bairros carentes. Daí a necessidade de mapear riscos, ou seja, identificar localidades de risco e representá-las graficamente, produzindo então mapas de risco. Uma vez identificadas as áreas de risco, é possível que os órgãos de proteção e defesa civil se articulem para que não haja novas ocupações no local e encaminhem e orientem os proprietários das residências de risco.

No mapa acima (figura 12) podemos perceber o quantitativo de áreas que apresentam risco à população Natividadense. E em grande parte das áreas de risco estão a população negra e de baixa renda da cidade, conforme evidencia a tabela 11, que confirma a discussão anterior de que houve um processo de urbanização desigual, com menos investimentos para a classe menos favorecida.

Essas evidências podem levar as autoridades competentes a tomarem medidas de contenção e realizarem um eficiente Planejamento Urbano das cidades com intuito de reduzir possibilidades de ocorrerem situações catastróficas. 
Com uma efetiva política habitacional de prevenção é possível evitar deslizamentos, soterramentos que culminam na remoção das pessoas para outros locais, alternativa ainda muito utilizada, após sucessivas perdas econômicas da população carente do município.

\section{7 -CONCLUSÕES}

Durante muito tempo os sociólogos e historiadores trataram a abolição como completada no dia 13 de maio de 1888 e que no tempo subsequente a população negra migrou de imediato para as grandes áreas urbanas. Também davam a entender que a imigração europeia foi em parte justificada pelo abandono das áreas rurais pela população negra. As pesquisas que estamos realizando em Natividade e em outras localidades, Petrópolis-RJ (SILVA-R., 2014), Juiz de Fora-MG (BATISTA, 2015), Carapicuíba-SP (MAVOUNGOU YADE, 2015) e Crato-CE (SILVA, M.; CUNHA JUNIOR, 2019), demonstra ao contrário, mostra uma migração constante entre as áreas rurais e urbanas e que havia uma parcela significativa de populações negras nas décadas de 1940 e 1950 trabalhando em atividades rurais, agrícolas e pecuárias e nesse período é que se dirigiram para área urbana devido a uma longa e trágica falência paulatina das econômicas agrárias na região. Ao longo dos anos houve decréscimos das produções de café e arroz, como também de outros produtos das economias de subsistência. Dentre os nossos entrevistados um senhor de 92 anos narrou com saudades os tempos (décadas de 1960 a 1990) em que existiam três maquinas de arroz beneficiando o produto na área dos armazéns de Natividade. Houve uma diminuição de possibilidades de trabalho para a população negra na região. Parte da população ativa saiu da região migrando para as grandes cidades do estado do Rio de Janeiro. A situação de vida de alguns dos bairros negros acabou sendo aliviada devido a migração para as grandes cidades.

Uma constatação do estudo dos bairros negros de Natividade é que eles se formaram em áreas de riscos e sem infraestruturas e intervenções urbanas que permitam a eliminação de grandes catástrofes e perdas materiais grandes as grandes enchentes, desmoronamentos e soterramentos. As dinâmicas periódicas das enchentes funcionam como várias histórias de perdas sucessivas de parte do patrimônio acumulado. Os novos 
bairros negros são implantados em área desvalorizadas da cidade e sem recursos de empregos, o que as tornam áreas estigmatizadas pela sociedade local.

Podemos concluir que os bairros negros demandam políticas publicas específicas e mesmo nas cidades pequenas eles se diferenciam significativamente dos bairros de maioria de população branca, principalmente pelas instalações em morros sem infraestrutura urbana. As populações de maioria branca moram em morros menos íngremes, com maior infraestrutura urbana e maior aplicação de recursos públicos. $\mathrm{O}$ traço marcante das histórias dos bairros negros de Natividade é de grande vulnerabilidade pela localização física.

\section{8-REFERÊNCIAS BIBLIOGRÁFICAS}

AURELIANO, Rodrigo. Quilombos Urbanos: Identidade Territorial e Desenvolvimento Social no bairro da Mata Escura Salvador-BA. X Seminário Estudantil de produção Acadêmica. Universidade Salvador, Salvador. 2006.. SEPA. Seminário Estudantil de Produção Acadêmica, v. x, p. http://www.unif, 2007.

BATISTA, Rita de Cássia Souza Félix. Clubes Sociais Negros: lugares de memória e identidade. 2015. Fortaleza: Tese (Doutorado em Educação) - Universidade Federal do Ceará, 2015

BEVILÁCQUA, Vanilsa Santana Oliveira. Serviços ecológicos de um rio de Floresta Atlântica: uma perspectiva social e ambiental. 2007. 119 p. Instituto de Ciências Biológicas da Universidade Federal de Juiz de Fora. Juiz de Fora,MG.

CARVALHO, Rosane Aparecida Bartholazzi. Imigrantes italianos em uma nova fronteira: Noroeste Fluminense (1896 - 1930). Dissertação (Mestrado) Universidade Severino Sombra Vassouras. 2001

CUNHA JUNIOR, Henrique. Bairros Negros: A Forma Urbana das Populações Negras no Brasil. Revista ABPN, v. 11, p. 65-86, 2019.

Cultura afrocearense. In: Artefatos da cultura negra no Ceará. CUNHA JUNIOR et al .(Orgs.). Fortaleza: Edições UFC, 2011. p. 102-132

Tecnologia africana na formação brasileira. Rio de Janeiro: CEAP, 2010.

. Nós, afro-descendentes: história africana e afrodescendente na cultura brasileira. In:

História da Educação do Negro e outras histórias. ROMÃO, Jeruse.(Org.). Secretaria de Educação Continuada, Alfabetização e Diversidade. - Brasília: Ministério da Educação, Secretaria de Educação Continuada, Alfabetização e Diversidade. 2005.p. 249-273

DIOP, Cheikh, Anta. The Cultural Unity of Negro Africa. Paris: Présence Africaine, 1963.

HENRIQUES, Major Porphírio. A terra da promissão: história de Itaperuna. Rio de janeiro: Gráfica Editora Aurora, 1956 
INEA - Instituto Estadual do Ambiente. Plano Estadual de Recursos Hídricos do Estado do Rio de Janeiro - Relatório Gerencial, 2014. Rio de Janeiro, 2014.

LIGIÉRO, Manoel. O Homem, o Rio e a Terra.1960.

LUZ, Narcimaria C. do Patrocinio. Do monopólio da fala sobre a educação a poesia mítica africano-brasileira. Salvador: Revista FAEEBA - Educação e contemporaneidade, vol. 12, numero 19, jan/ jun, 2003.

MAVOUNGOU YADE, Juliana de Souza. Vozes e Territorialidades no Pós-Abolição: histórias de famílias e resistência identitária. Fortaleza: Tese (Doutorado em Educação) - Universidade Federal do Ceará, 2015.

OLIVEIRA, José Reinaldo de; OLIVEIRA, Regina Marques de Souza. Origens da Segregação Racial no Brasil. Amérique Latine Histoire \& Memoire, Les Cahiers ALHIM. Paris, 29. ed., jun, 2015. Disponível em: Acesso em: 26 jun. 2018

PAIVA, E. F. Bateias, carumbés, tabuleiros: mineração africana e mestiçagem no Novo Mundo. In ANASTASIA, Carla M. J. \& PAIVA, Eduardo F. O trabalho mestiço - maneiras de pensar e formas de viver, séculos XVI a XIX. São Paulo: Annablume: PPGH/ UFMG, 2002.

PAULA, Renata Souza Poubel de. Expansão urbana e segregação socioespacial em Itaperuna: o caso do território Jardim Surubi. 2018. 103 f. (Mestrado em Planejamento Regional e Gestão de Cidades) Programa de Pós-Graduação em Planejamento Regional e Gestão de Cidades. Universidade Candido Mendes, Campos dos Goytacazes, RJ.

PEREIRA JÚNIOR, Arthur Rodrigues. Itaperuna (RJ) no contexto regional no Noroeste Fluminense: um movimento entre a centralidade e a descentralidade. 2015. $160 \mathrm{f}$. (Mestrado em Dinâmicas Regionais) - Programa de Pós-Graduação em Planejamento Regional e Gestão de Cidades. Universidade Cândido Mendes, Campos dos Goytacazes, RJ.

ROLNICK, Raquel. Solo urbano e habitação de interesse social: a questão fundiária na política habitacional e urbana do país.

SANTOS, Rui Junio Fonseca. A segregação sócio-espacial na cidade de Itaperuna (RJ). Campos dos Goytacazes(RJ):2018. 120 f. Dissertação (Mestrado em Desenvolvimento, Ambiente e Políticas Públicas) - Universidade Federal Fluminense, Campos dos Goytacazes, RJ.

. A formação urbana da cidade de Itaperuna (RJ) e suas implicações sobre o Rio Muriaé. XVII ENAMPUR, 2017

SILVA, M. M. da; CUNHA JUNIOR, H.. Percursos urbanos como forma de pesquisar o patrimônio afrocratense. GEOTEXTOS (ONLINE), v. 15, p. 199, 2019.

SILVA, Maria Nilza da. O negro em Londrina: da presença pioneira negada à fragilidade das ações afirmativas na UEL.Revista Espaço Acadêmico, nº 82, 2008.

SILVA, Maria Nilza. Nem para todos é a Cidade: O negro na cidade de São Paulo. 2006.

SILVA, Olintho Pereira da. A mineração em Minas Gerais: passado, presente e FuturoGEONOMOS, vol.3, no.1, IGC-UFMG,1995. 
SILVA, R. A. da ; CUNHA JUNIOR, H.. Cidades Negras - Petrópolis Imperial. Revista Ambivalências, v. 2, p. 81, 2014.

SILVA, Renata Aquino da. Afroinscrições Negras em Petrópolis - Historia Urbana, Memória e Territorialidade. Fortaleza: Tese (Doutorado em Educação) - Universidade Federal do Ceará,2018.

SOUZA, J.; CUNHA JUNIOR, H. A inscrição de um território negro urbano: introdução a uma pesquisa em Carapicuíba - SP. Revista África e Africanidades, v. 12, p. 01-14, 2011.

SOUZA, Márcia Aparecida de; CUNHA JUNIOR, Henrique. Festança de família negra tradicional do interior do Rio de Janeiro: memória, história e patrimônio cultural da população negra. In: Afro patrimônio cultural. SANTOS, Marlene Pereira dos; CUNHA JÚNIOR, Henrique. (Org.) Fortaleza, CE: Editora Via Dourada, 2019.

SOUZA, Márcia Aparecida de; CUNHA JUNIOR, Henrique. Bairros negros e suas formações na cidade de Natividade-RJ. In: Bairros negros cidades negras. CUNHA JÚNIOR, Henrique; BIÉ, Estanislau Ferreira.(Org.). Fortaleza, CE: Editora Via Dourada, 2019.

Recebido em: 22/09/2020

Aceito em: 30/10/2020 